e-Jurnal Ilmiah BIOSAINTROPIS (BIOSCIENCE-TROPIC)

Volume 5/ No.: 1 / Halaman 1 - 6 / Agustus Tahun 2019

ISSN : 2460-9455 (e) - 2338-2805(p)

\title{
Dinamika Populasi Jamur Pada Media Starter Tepung Beras Diperkaya Nutrisi PDA
}

\section{The Dynamics The Population of Cells Fungus On The Media Starter Rice Flour Enriched Nutrients PDA}

\author{
Anindyta Rhobiatul Addawiyah ${ }^{* 1)}$, Ahmad Syauqi ${ }^{* * 2)}$, Hasan Zayadi ${ }^{3}$ \\ 123) Jurusan Biologi, Fakultas Matematika dan Ilmu Pengetahuan Alam, Universitas Islam Malang, Indonesia
}

\begin{abstract}
ABSTRAK
Jamur berperan penting di dalam industri makanan dan jamur dapat berkembangbiak di dalam suatu media. Tepung beras merupakan salah satu alternatif bahan dasar media terbuat dari tepung komposit yang mengandung karbohidrat, lemak, protein, mineral dan vitamin. Starter berupa jamur dalam jumlah dan kondisi fisiologis dapat diinokulasikan pada media fermentasi. Penelitian bertujuan mempelajari dinamika populasi jamur pada pembuatan starter dengan media tepung beras kaya nutrisi Potato Dextrose Agar (PDA). Potato Dextrose Agar (PDA) merupakan salah satu media yang baik digunakan untuk membiakkan suatu mikroorganisme, baik itu berupa cendawan atau fungsi, bakteri, maupun sel mahluk hidup. Metode yang digunakan pada penelitian ini adalah metode Uji beda rerata dua populasi dengan 2 variabel dengan kadar PDA $0 \%$ dan $4 \%$ dengan 9 kali ulangan. Yang mana pada setiap 8 jam sekali diamati dinamika pertumbuhan jamurnya dengan mengidentifikasi spesies jamur sebagai berikut Aspergillus niger berwarna putih dan berbenang, Candida utilis berwarna putih, Hansenulla saturnus berwarna buram, dan Trichoderma viride berwarna bening.
\end{abstract}

Kata Kunci : Tepung beras, Ragi, PDA (Potato Dextrose Agar), Aspergillus niger, Candida utilis, Trichoderma viride, Hansenula saturnus.

\begin{abstract}
Yeast and fungus are important biomass in the food industry. Rice flour is one of the alternative basic ingredients of composite flour and consists of carbohydrates, fats, proteins, minerals and vitamins. Yeast multiplies by a process known as germination, which causes fermentation. This study aims to determine the development of fungal cell population dynamics in making starter with rice flour rich in PDA (Potato Dextrose Agar) nutrition. PDA (Potato Dextrose Agar) is one of the good media used to breed a microorganism, either in the form of fungus / function, bacteria, or living cells. The method used in this study is a different test method for two populations with 2 variables with PDA levels of $0 \%$ and $4 \%$ with 9 times of repetition. Which is observed once every eight hours the growth dynamics of the fungus by identifying the following fungal species Aspergillus niger is white and has a good composition. Candida utilis is white. Hansenulla anomala is opaque, Trichoderma viride is clear.
\end{abstract}

Keywords: Rice flour, Yeast, PDA (Potato Dextrose Agar), Aspergillus niger, Candida utilis, Trichoderma viride, Hansenula saturnus.

*) Anindyta Rhobiatul Addawiyah Jurusan Biologi FMIPA UNISMA, Jl. MT Haryono 193, Malang 65144, 0853381674, e- mail: Anin.dyta1307@gmail.com

**) Ir. Ahhmad Syauqi, M.Si, Jurusan Biologi FMIPA UNISMA, Jl. MT Haryono 193, Malang 65144, 08986307836 email: ahmadandro.as@gmail.com

Diterima Tanggal 20 Agustus 2018 - Publikasi Tanggal 25 Agustus 2019 
e-Jurnal Ilmiah BIOSAINTROPIS (BIOSCIENCE-TROPIC)

Volume 5/ No.: 1 / Halaman 1 - 6 / Agustus Tahun 2019

ISSN : 2460-9455 (e) - 2338-2805(p)

\section{Pendahuluan}

Salah satu alternatif bahan dasar untuk pembuatan media adalah tepung yang terdiri atas karbohidrat, lemak, protein, mineral dan vitamin adalah tepung beras. Tepung beras adalah produk setengah jadi untuk bahan baku industri lebih lanjut. Uuntuk membuat tepung beras membutuhkan waktu Selama 12 jam dengan cara beras direndam dalam air bersih, ditiriskan, dijemur, dihaluskan dan diayak menggunakan ayakan 80 mesh [1]

Komponen yang utama ada dalam beras adalah karbohidrat. Karbohidrat di dalamnya terdiri dari pati merupakan bagian besar dan bagian kecil beras adalah gula, selulosa, hemiselulosa dan pentosa. Pati yang ada dalam beras $85-90 \%$ dari berat kering beras, pentosa $2,0-2,5 \%$ dan gula 0,6$1,4 \%$ dari berat beras pecah kulit. faktor yang dapat menentukan sifat fisikokimia dari beras karena itu merupakan sifat-sifat pati [2]

Media isi mikroba tertentu dan digunakan untuk memacu tumbuhnya mikroba starter merupakan yang diharapkan. Starter komersil banyak dijual, misalnya ragi tape, ragi kue, EM4, Starbia dan lain-lain. Wujud starter beragam, tergantung dari mikroba yang dikandungnya. Starter yang mengandung jamur atau ragi berbentuk kering, sedangkan starter bakteri berbentuk cair.

Media isi mikroba yang sudah diinaktifkan (immobil ) adalah starter. Kebutuhan mikroba terhadap energi demikian rendah dalam keadaan inaktif. Dengan demikian, pemanfaatan energi yang terkandung dalam media starter menjadi lambat sehingga kehidupan mikroba didalam starter dapat bertahan lama. Hal ini dapat dimanfaatkan untuk pembuatan etanol [3][4]

Pada dasarnya teknik pembuatan starter digunakan di dalam memperbanyak mikroorganisme. Perbanyakan mikroba yang tumbuh ini dilakukan dalam suatu medium tertentu dan setelah cukup banyak, pertumbuhannya dihentikan serta dibuat dalam keadaan istirahat, baik dalam bentuk sel maupun dalam bentuk sporanya. Penghentian pertumbuahn mikroba tersebut dilakukan dengan cara mengeringkan medium tumbuhnya.

Salah satu media agar yang cocok dan mendukung pertumbuhan jamur adalah Potato Dextrose Agar (PDA) yang merupakan media terdiri atas dextrose, sari kentang dan agar. Pertumbuhan jamur didalam media PDA dapat dihindarkan dari kontaminasi bakteri dengan cara mengatur media pada keasaman media pada ( $\mathrm{pH} 4,5$ sampai 5,6) sehingga menghambat pertumbuhan bakteri yang membutuhkan lingkungan yang netral dengan $\mathrm{pH} 7,0$, dan suhu optimum pertumbuhannya antara $25-30{ }^{\circ} \mathrm{C}$.

Berdasarkan uraian di atas maka di lakukan penelitian dengan judul Dinamika Populasi Jamur Pada Pembuatan Starter Dengan Media Tepung Beras Kaya Nutrisi PDA. Yaitu perubahan populasi jamur berdasar waktu. [5]

\section{Material dan Metode}

Bahan yang digunakan dalam penelitian adalah : inokulasi jamur Candida sp, Hansenulla saturnus, Aspergillus niger, dan Trichoderma viride, Alkohol 70\%, tepung beras, aquades, PDA (Potato Dekstrosa Agar). $\mathrm{FeSO}_{4} 7 \mathrm{H}_{2} \mathrm{O} ; \mathrm{MgSO}_{4} 7 \mathrm{H}_{2} \mathrm{O} ; \mathrm{CaCl}_{2} 2 \mathrm{H}_{2} \mathrm{O} ; \mathrm{CuSO}_{4}, \mathrm{HCl}$, dextrosa.

Alat yang digunakan adalah Mikroskop, Timbangan analitik, pengaduk kaca, kapas, kertas sampul, benang, Tabung Reaksi, gelas beaker, Pipet Ukur, Inkubator, Hot Plate, Autoklav, Erlenmeyer, Alumunium Foil, gelas ukurr, cawan petri, pipet, plastik klip,bunsen, baskom, kamera.

Penelitian ini merupakan penelitian eksperimental Uji beda rerata dua populasi dengan 9 kali ulangan waktu.

Penelitian ini dimulai dengan sterilisasi alat, pembuatan medium wang, pembuatan kultur jamur, prnyaringan jamur, pembuatan starter, pembuatan medium PDA, perhitungan sel jamur.

Sterilisasi alat dengan cara membungkus alat yang akan digunakan (hanya alat yang bisa dibungkus) dengan kertas coklat dan diikat dengan benang kasur, kemudian dimasukkan kedalam autoclave untuk sterilisasi pada suhu $121^{\circ} \mathrm{C}$ dengan tekanan $15 \mathrm{lbs}$ selama 15 menit. 
e-Jurnal Ilmiah BIOSAINTROPIS (BIOSCIENCE-TROPIC)

Volume 5/ No.: 1 / Halaman 1 - 6 / Agustus Tahun 2019

ISSN : 2460-9455 (e) - 2338-2805(p)

Pembuatan medium Wang $200 \mathrm{ml}$ dilakukan dengan menimbang 0,055g $\mathrm{FeSO}_{4} 7 \mathrm{H}_{2} \mathrm{O} ; 0,3$ $\mathrm{MgSO}_{4} 7 \mathrm{H}_{2} \mathrm{O} ; 0,025 \mathrm{~g} \mathrm{CaCl}_{2} 2 \mathrm{H}_{2} \mathrm{O} ; 0,05 \mathrm{CuSO}_{4}$, dicampur dengan aquades $200 \mathrm{ml}$ di aduk sampai merata, $\mathrm{pH} 5,1$ dibuat dengan penambahan $\mathrm{HCl} 3 \%$, kemudian ditambahkan dektosa $5 \%$.

Dibuat medium wang $200 \mathrm{ml}$, kemudian dicampur dengan dektrosa sebanyak $10 \mathrm{~g}$ dan tetes tebu $12 \mathrm{~g}$ dimasukkan ke dalam erlenmeyer $250 \mathrm{ml}$, dishaker selama 7x24 jam, kemudian di masukkan ke dalam inkubator dengan suhu $31^{\circ} \mathrm{C}$ selama 14 hari sampai tumbuh jamur.

Setelah 14 hari kultur dan tumbuh jamur, jamur dikeluarkan dari inkubator kemudian disaring dengan menggunakan kertas saring lalu jamur disiram dengan aquades agar tetes tebu tidak menempel pada jamur dan jamur siap digunakan.

Dengan mengunakan media PDA sebanyak $0 \%$ dan $4 \%$ dalam $100 \mathrm{~g}$ tepung beras, dicampur kultur Aspergillus niger, Candida sp, Hansenulla saturnus, Trichoderma viride yang telah disiapkan dan sudah disaring, kemudian diinokulasi pada media PDA yang telah disiapkan. Ditambah aquades secukupnya lalu diaduk sampai merata. Dibentuklah adonan ragi yaitu bulat pipih. Kemudian dipindahkan di wadah plastik yang diberi lubang - lubang kecil lalu dimasukkan ke dalam gelas beaker dan ditutup dengan alumunium foil dengan diberi lubang - lubang kecil. Disimpan selama 48 jam dan diamati pertumbuhan jamurnya setiap 8 jam sekali sampai 64 jam.

Media PDA dibuat dengan menimbang PDA seberat 26 g kemudian dilarutkan dengan 1000 $\mathrm{ml}$ aquades steril. Dimasukkan medium tersebut ke dalam erlenmeyer, lalu dipanaskan sambil diaduk di atas hot plate sampai larutan homogen dan mendidih, media disterilkan dengan autoklaf selama 15 menit dengan temperatur $121^{\circ} \mathrm{C}$. Disiapkan cawan petri steril lalu dituangkan kira - kira $15 \mathrm{ml}$, kemudian cawan ditutup ditunggu sampai dingin dan mengeras.

Untuk pengenceran starter yang telah dibuat dengan medium tepung beras dan PDA diambil 1 gram lalu dimasukkan ke dalam erlenmeyer $250 \mathrm{ml}$ kemudian diencerkan dengan menambahkan aquades sebanyak $100 \mathrm{ml}$ dan diambil $1 \mathrm{ml}$ ke dalam tabung reaksi ditambah aquades $10 \mathrm{ml}$ pengenceran $10^{3}$, diambil $1 \mathrm{ml}$ ke dalam tabung reaksi ditambah aquades $10 \mathrm{ml}$ pengenceran $10^{4}$, kemudian diambil $1 \mathrm{ml}$ dan ditanam pada cawan petri steril yang sudah berisi media PDA yang telah mengeras, di goyang dengan membentuk angka delapan, diinkubasi pada suhu $30^{\circ} \mathrm{C}$ selama 48 jam. Lalu dihitung koloni setiap spesiesnya.

\section{Hasil dan Diskusi}

Pada hasil penelitian yang telah dilakukan pada jam ke 0 dengan perlakuan media tepung beras tanpa PDA jamur yang tumbuh dari spesies Aspergillus niger memiliki warna koloni hitam, konidia hitam dengan bintik - bintik hitam di atas permukaannya dengan jumlah $0,01 \times 10^{6}$ sampai pada jam ke 16, pada jam berikutnya hasil pertumbuhannya terus menurun dan tumbuh pada jam ke $48-64$ jam dengan jumlah yang sangat sedikit yaitu $0,05 \times 10^{6}$ dan $0,01 \times 10^{6}$. Pada media tepung beras dengan tambahan 4\% PDA spesies Aspergillus niger pada jam ke 0 sebanyak $0,01 \times 10^{6}$ pada jam ke 8 - 16 tidak ada pertumbuhan, jam ke 24 sebanyak $0,65 \times 10^{6}$, jam ke 32 tidak ada pertumbuhan, pada jam ke 40 mengalami peningkatan sebanyak $0,82 \times 10^{6}$, jam ke $48-64$ jam mengalami penurunan yaitu dengan jumlah $0,02 \times 10^{6}$. Menurut referensi [6], pertumbuhan Aspergillus niger dipengaruhi secara langsung oleh nutrisi yang terkandung di dalam medium pertumbuhannya. Nutrisi-nutrisi tersebut dapat digunakan sesudah Aspergillus niger mengekskresi enzim-enzim ekstraselular yang dapat memecah senyawa kompleks dari substrat tersebut menjadi senyawa yang lebih sederhana [7].

Pada grafik di atas dapat dilihat bahwa pertumbuhan jamur Aspergillus niger mengalami kenaikan yang cukup tinggi pada jam ke 16 dengan media tepung beras tanpa PDA, pada media tepung beras dengan penambahan PDA 4\% pertumbuhannya merata. Pertumbuhan jamur Aspergillus niger lebih bagus dengan media tepung beras dengan penambahan PDA $4 \%$. 


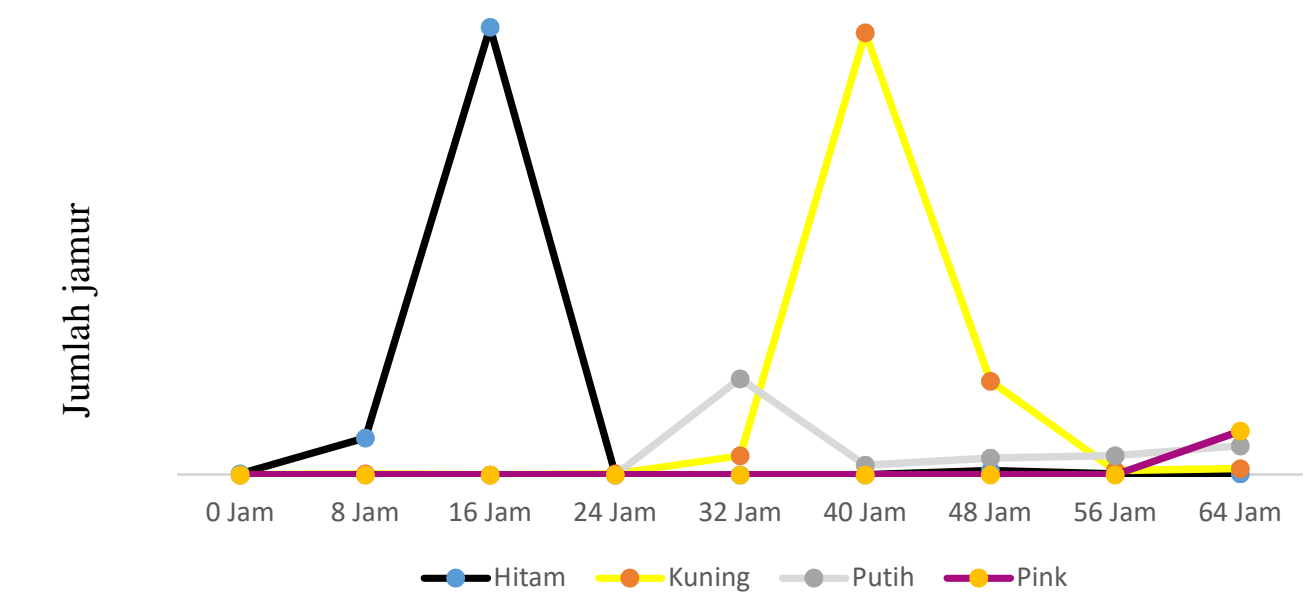

Keterangan : hitam : Aspergillus niger, kunimg : Hansenula saturnus, Putih : Candida sp, Pink : Trichoderma viride.

Gambar 1. Grafik Pertumbuhan Sel Jamur dengan Kadar PDA $0 \%$

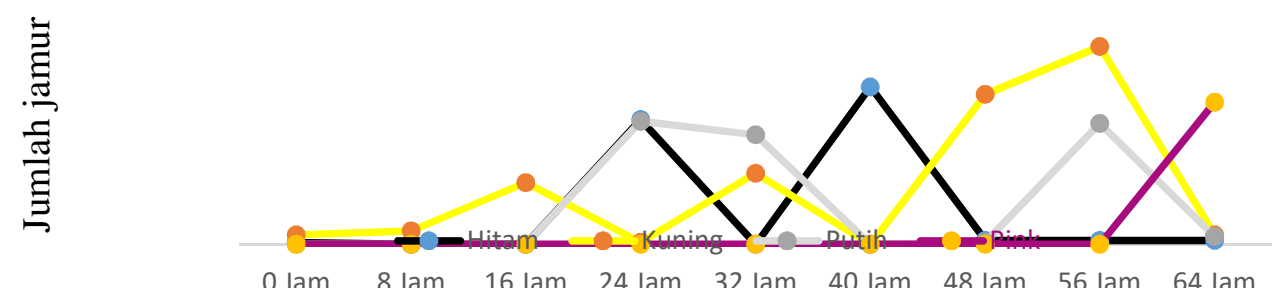

Keterangan : hitam : Aspergillus niger, kunimg : Hansenula saturnusa, Putih : Candida sp, Pink: Trichoderma viride.

Gambar 2. Grafik Pertumbuhan Sel Jamur dengan Kadar PDA $4 \%$

Spesies Hansenula saturnus memiliki warna koloni kuning, berbentuk silindris, mengalami pertumbuhan sedikit demi sedikit pada jam ke 0 dan ke 16 tidak ada petumbuhan, jamur Hansenula saturnus tumbuh pada jm ke 8 sebanyak $0,01 \times 10^{6}$, jam ke $24-64$ jam tumbuh dengan jumlah yang naik turun dan puncak tertinngi pertumbuhannya pada jam ke 40 dengan jumlah koloni 5,06 x $10^{6}$. Pada media tepung beras dengan tambahan 4\% PDA spesies Hansenula saturnus pada jam ke $0-32$ jam mengalami pertumbuhan dengan jumlah yang naik turun, jam ke 40 tidak ada pertumbuhan, jam ke 48 - 64 naik $0,78 \times 10^{6}$ dan $10,3 \times 10^{6}$ dengan puncak tertinggi pada jam ke 56, terjadi penurunan pada jam ke 64 yaitu $0,05 \times 10^{6}$. Hansenula saturnus menunjukkan tingkat pertumbuhan 0,22 dan 0,056 jam-1 dan hasil biomassa 0,59 dan $0,11 \mathrm{~g} / \mathrm{g}$ glukosa dibawah kondisi aerobic dan anaerobic masing-masing. 
e-Jurnal Ilmiah BIOSAINTROPIS (BIOSCIENCE-TROPIC)

Volume 5/ No.: 1 / Halaman 1 - 6 / Agustus Tahun 2019

ISSN : 2460-9455 (e) - 2338-2805(p)

Jamur Hansenula saturnus pada media tepung beras dengan kadar PDA $0 \%$ pertumbuhannya merata dibandingkan dengan media tepung beras dan PDA $4 \%$ yang pertumbuhannya tidak merata, pada jam ke 48 mengalami kenaikan yang cukup tinggi kemudian pada jam ke 48 mengalami penurunan sampai jam ke 64 .

Untuk spesies Candida sp memiliki warna koloni putih, bersel satu, pada jam ke $0-24$ jam tidak ada pertumbuhan, jumlah paling banyak pada jam ke 32 yaitu $1,1 \times 10^{6}$ dan mengalami penurunan pada jam ke 40 tetapi pada jam berikutnya terjadi pertumbuhan yang terus meningkat sampai jam ke 64. Pada media tepung beras dengan tambahan 4\% PDA spesies Candida sp pada jam ke $0-16$ jam tidak ada pertumbuhan, pada jam ke 24 tumbuh $0,64 \times 10^{6}$, jam ke 32 dengan jumlah $0,57 \times 10^{6}$, jam ke 40 tidak ada pertumbuhan, pada jam ke 48 mengalami penurunan dan pada jam ke 56 meningkat

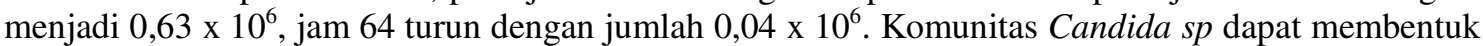
asosiasi koloni yang disebut biofilm. Biofilm merupakan alat pelindung bagi mikroba terhadap respon imun sel inang dan zat anti mikroba. Candida sp tergolong yeast (khamir) mampu menghasilkan enzim-enzim yang berfungsi dalam metabolisme anatara lain glukoprotein seperti invertase, melibiase, fosfatase, glukanase, selulase, ( $\beta$-glukosidase), fosfolipase, dan protease. Enzim-enzim ini berikatan secara kovalen dengan mannan dan glukan dalam dinding sel.

Pertumbuhan jamur Candida sp pada media tepung beras tanpa PDA pertumbuhannya cukup baik dibandingkan dengan media tepung beras dengan penambahan PDA 4\% karena pada jam ke 64 untuk yang ditambah PDA 4\% mengalami penurunan, berbeda dengan kadar PDA 0\% pada jam ke 40 mengalami penurunan tetapi pada jam berikut terus mengalami kenaikan sampai jam ke 64 .

Trichoderma viride yang memiliki warna hijau, tangkai fialid, tetapi pada hasil penelitian memiliki warna pink memiliki konidiofor bercabang - cabang teratur, konidium jorong, bersel satu dan pada jam ke 0 - 56 tidak ada pertumbuhan, pertumbuhan terjadi pada jam ke 64 saja dengan jumlah $0,5 \times 10^{6}$. Pada media tepung beras dengan tambahan 4\% PDA spesies Trichoderma viride pada jam ke 0 - 56 tidak ada pertumbuhan, pertumbuhan terjadi pada jam ke 64 saja dengan jumlah $0,74 \times 10^{6}$. Jamur Trichoderma viride pertumbuhannya terjadi pada jam ke 64 baik yang media tepung beras tanpa PDA maupun dengan tambahan PDA 4\%, tetapi pertumbuhannya lebih bagus yang media tepung beras dengan penambahan PDA 4\%. Semua spesies tumbuh tetapi pertumbuhan populasi tidak disebabkan oleh faktor waktu.

hubungan interaksi antara ke empat jamur tersebut sinergisme adalah hubungan antara dua spesies atau lebih yang dicirikan oleh keuntungan bagi setiap spesies yang melakukan kehidupan bersama, dan seakan - akan merupakan suatu urut - urutan dalam penggunaan sumber energi. Ciri lainnya adalah kebalikan dari simbiosis/mutualisme, yaitu secara fisik tidak dekat/menyatu. Contohnya adalah mikroba dalam ragi tape yaitu golongan jamur mikroskopis (fungi) berbentuk benang; Aspergilus oryzae, Aspergillus niger dan satu sel; Hansenula malanga atau Hansenula saturnus, Candida sp, Saccharomyces cerevisiae, serta bakteri Acerobacter aceti. Penelitian yang dilakukan oleh mahasiswa dan dosen di FMIPA Unisma diketahui bahwa poiner untuk kehidupan kerja sama mereka adalah dominasi jamur berbentuk benang dan selanjutnya khamir serta bakteri [3].

Spesies Trichoderma sp [4] ditambahkan untuk hubungan sinergis di atas tanpa spesies bakteri Acetobacter aceti. Sehingga berdasarkan hal itu diketahui peningkatan glukosa yang siperankan oleh enzim ekstraseluler selulase yang dimiliki oleh Trichoderma sp. Hubungan sinergisme baru sebagai suatu konsorsium jamur Trichoderma sp, Aspergillus niger, Hansenula sp dan Candida sp dapat dimanfaatkan untuk proses sakrifikasi dari polimer amilosa, amilopektin, dan selulosa yang menghasilkan glukosa. Selanjutnya dengan Saccharomyces cerevisiae baik dilakukan bersama - sama dalam substrat maupun terpisah dapat menghasilkan etanol untuk bahan bakar motor maupun kepentingan kesehatan dan bukan untuk kepentingan minuman beralkohol. Terdapat potensi untuk menghasilkan enzim pemecah polimer pati dan selulosa secara mudah dalam usaha produksi bahan bakar terbarukan.

Pertumbuhan jamur dipengaruhi oleh faktor substrat, kelembaban, suhu, derajat keasaman substrat $(\mathrm{pH})$, dan senyawa - senyawa kmia dilingkungannya. Sumber nutrien utama bagi jamur merupakan substrat. Sesudah jamur mengekresi enzim - enzim ekstraseluler yang dapat dimanfaatkan 
e-Jurnal Ilmiah BIOSAINTROPIS (BIOSCIENCE-TROPIC)

Volume 5/ No.: 1 / Halaman 1- 6 / Agustus Tahun 2019

ISSN : 2460-9455 (e) - 2338-2805(p)

nutrien nutrien dalam substrat tersebut nutrien - nutrien baru dapat dimanfaatkan. umumnya jamur tingkat rendah seperti Rhizopus atau Mucor memerlukan lingkungan dengan kelembapan nisbi 90\%, sedangkan kapang Aspergillus, Penicilium, Fusarium, banyak Hyphomycetes lainnya dapat hidup pada kelembapannisbi yang lebih rendah, yaitu $80 \%$. Sekitar $25-30^{\circ} \mathrm{C}$ suhu untuk pertumbuhan kebanyakan jamur. Fungi menyenangi $\mathrm{pH}$ dibawah 7,0 pH 4,5 - 5,5 untuk beberapa khamir. senyawa - senyawa yang tidak diperlukannya lagi dan dikeluarkan ke lingkungan oleh jamur.

\section{Kesimpulan}

Berdasarkan hasil dan pembahasan dapat diambil kesimpulan bahwa pertumbuhan jamur dengan kadar PDA $0 \%$ pertumbuhannya rendah, seperti pada jamur Aspergillus niger jam ke 16 meningkat tajam tetapi pada jam ke 24 menurun drastis sampai jam berikutnya terus mengalami penurunan, begitu juga dengan jamur Hansenula saturnus terjadi peningkatan pada jam ke 48. Semua populasi jamur telah tumbuh pada jam ke 64 . Sedangkan pertumbuhan jamur dengan kadar PDA $4 \%$ lebih tinggi dengan peningkatan jamur di setiap 8 jamnya pertumbuhan populasi disebabkan oleh faktor waktu dan limgkungan.

\section{Daftar Pustaka}

[1] Hasnelly dan Sumartini. 2011. Kajian sifat fisiko kimia formulasi tepung komposit produk organik. Seminar Nasional PATPI.375-379.

[2] Haryadi. (2006). Teknologi Pengolahan Beras. Gadjah Mada University Press.

[3] Syauqi, A. 2008. Membentuk Konsorium Jamur Aspergillus niger, Trichoderma sp, Hansenula sp, Candida sp, Saccharomyces cerevisiae Untuk Produksi Alkohol dari Ubi Kayu (Manihot esculenta Crantz). Dibiayai oleh direktorat jendral pendidikan nasional sesuai dengan surat perjanjian pelaksanaan hibah penelitian nomor: 231/SP2H/PP/DP2M/III/2008. Fakultas Matematika dan Ilmu Pengetahuan Alam. Universitas Islam Malang. Malang.

[4] Syauqi, A. 2017. Sinergistic Fungi Activity For Perleminary Genetic Engineering Of Microba to Etanol Fermentation. Akses Tanggal $14 \quad$ september 2018 (http://www.researchgate.net/publication/312589275_sinergic_fungi_activity_for_perlemina ry_genetic_engineering_of_microba_to_etanol_fermentation_sinergitic_fungi)

[5] Syauqi, A. 2017. Microbiologi Lingkungn Peranan Mikroorganisme Dalam Kehidupan. Universitas Islam Malang. Malang-ANDI. Yogyakarta. Halaman 169-186.

[6] Asmaria, 2009. Pemamfaatan Tepung Kulit Buah Kakao Terong Belanda Fermentasi (Aspergillus Niger) terhadap Kinerja Reproduksi Burung Puyuh. Skripsi. Fakultas Pertanian Universitas Sumatera Utara. Medan.

[7] Muhtar, M. 2013. Pemanfaatan Kullt Buah Kakao Sebagai Media padat Untuk Memproduksi Enzim Amilase Oleh Aspergillus niger dan Aspergillus oryzae. SkripsiFakultas Pertanian Universitas Hasanuddin Makassar. Makassar. 